\title{
Daughter Zion's Contemporary Sibling \\ Dalit Assertions vis-à-vis a Postcolonial Reading of the Book of Lamentations
}

\author{
Dominic S. Irudayaraj SJ
}

Hekima University College, Nairobi Pontifical Biblical Institute, Rome irudayaraj@biblico.it

\begin{abstract}
Taking a cue from a perceptive and a widely-received work of Carleen Mandalfo (Daughter Zion Talks Back to the Prophets: A Dialogic Theology of the Book of Lamentations), the present paper aims to glean some of the salient multi-disciplinary insights of the author. The same insights are grouped around some of the salient postcolonial features that R. S. Sugirtharajah outlines, which together constitute postcolonial construal with attendant illustrations. Then, the paper shifts the spotlight on commensurate features in contemporary Dalit assertions from the Indian subcontinent in order to propose that the latter can be viewed as a meaningful, contemporary sibling of Daughter Zion. Despite the chronological and cultural distances between the Dalits and Daughter Zion of Lamentations, it is proposed here that the assertions of these two likewise siblings may profitably be appropriated by today's readers of courage and commitment in order to come to terms with the angsts and outbursts of people, particularly of those who reel under immense pain and fissure.
\end{abstract}

\section{Keywords}

Dalit, Daughter Zion, Lamentations, Postcolonial perspective, discursive resistance 


\section{INTRODUCTION}

In the great vicinity of death, of blood, and of soil, the mind takes on harder features and darker colors. ${ }^{1}$

We live in a world that is continually confronted by the presence of massive suffering. ${ }^{2}$ When a person undergoes intense pain or suffering, s/he slips into moments of crisis that may peak in trauma. ${ }^{3}$ The effect can be graver still if the suffering is induced by others. What is said of an individual is equally applicable for a community of persons. Such a community, then, goes through a painful process of coming to terms with the afflicting situation. The process can encompass one or more of the behavioral patterns such as: silence as resignation, silence as passive aggression, refusal to accept the reality, anger/rage, or thirst for revenge. There is yet another, albeit subtle, way of coming to terms with grueling realities of life: constructing a counter-story which questions, subverts and at times even ridicules the dominant story that legitimizes the community's current state of sad affairs.

Within one's faith arena, such grappling with the reality of suffering is often accompanied by asking an ever-challenging question of theodicy: How can one's belief in a loving and powerful God be reconciled with the presence of evil in the world? So exclaims Jon Sobrino and continues, "It is the quandary of theodicy which ... becomes the problem of love's impotence vis-à-vis sin, of the impotence of good vis-à-vis evil." 4 In the history of Israelites there were moments when this most troubling

1 A quote by Ernest Junger (Der Arbeiter, 1932). As cited in Anton Kaes, Shell Shock Cinema:Weimar Culture and theWounds of War (New Jersey: Princeton University Press, 2009), 145 .

2 Much has been written on this ubiquitous human experience. On the biblical notion of "Suffering," for example, see Anthony J. Tambasco, ed., The Bible on Suffering: Social and Political Implications (New York: Paulist Press, 2001). See also Carroll Stuhlmueller and Dianne Bergant, The Collegeville Pastoral Dictionary of Biblical Theology (Collegeville, MN: Liturgical Press, 1996), 965.

3 Building on interdisciplinary insights from psychology, sociology, and cultural studies, one of the growing interpretive sensibilities in the past few years have rightly been on "trauma" and its impacts at the individual, social, and literary levels. See Elizabeth Boase and Christopher G. Frechette, Bible through the Lens of Trauma, SBL Semeia Studies 86 (Atlanta, GA: SBL Press, 2016). Of particular significance to the present paper is the way such painful experiences leave their traces at the literary level, especially in the form of contestations.

${ }^{4}$ Jon Sobrino, Christology at the Crossroads: A Latin American Approach, trans. John Drury (New York: Orbis Books, 1978), 224. 
question had to be posed and come out with ways and means of coping with them. According to some biblical scholars, one such outcome was the book of Lamentations. ${ }^{5}$ However and as relevantly problematized by Miriam Bier, a closer scrutiny of the same corpus would hardly permit such a singular, straightforward explanation. The pain and penitence, the protest and contestation together constitute a polyphony that characterizes the book. Therein can one find, to toe the inquiry lines of Mandalfo, the promising possibility of perceiving and paying attention to the hitherto sidelined groans and sighs of Daughter Zion and the concomitant, challenging invitation to its committed readers.

This paper, therefore, takes its initial cue from Mandalfo's passionate rendering of an overwhelming grief and the protesting "talk back" of Daughter Zion. As such, Mandalfo's reading strategy, which includes postcolonial sensibility, brings out some of the characteristic features of texts that are produced during times of crisis. From a methodological perspective, the said features catalogued under some of the postcolonial features that Sugirtharajah outlines. Together, they would constitute a perspective (postcolonial) and its practice (for Lamentations).

The paper then turns its attention to one of the contemporary groups that shares similar features, namely, crises that lead to meaning-making process of which producing a counter-story forms a significant part. The socially ostracized Dalit community in India will form the case study. Based on the observation that similar features - especially, discursive can be observed in these two traumatized groups, the focus then turns inward and poses the question of theological ramification. What does it mean to be a theologian ${ }^{6}$ when we approach these difficult and challenging questions that are raised by crisis-confounded groups? The paper concludes by suggesting that a reader/theologian of courage and commitment can draw upon the proposals of Mandolfo, ${ }^{7}$ together with those

5 For a survey of theodic and antitheodic reading of the book of Lamentations, see Miriam J. Bier, "Perhaps There Is Hope": Reading Lamentations as a Polyphony of Pain, Penitence, and Protest, LHBOTS 603 (London: Bloomsbury T\&T Clark, 2015), 12-31.

6 Here, the term "theologian" is understood not so much as limited to someone with an academic training in theology as any committed reader who engages the biblical texts for their import for current contexts. Hence, "theologian" and "reader" are used synonymously in this paper.

7 Carleen R. Mandolfo, Daughter Zion Talks Back To The Prophets: A Dialogic Theology of the Book of Lamentations, SBL Semeia Studies 58 (Atlanta, GA: SBL, 2007). 
of Walter Bruggamann, ${ }^{8}$ and Karen Baker-Fletcher ${ }^{9}$ in order to find immense relevance in the protesting voices that continue to engage the hegemonic discourses-including, the theological one!

\section{The Book of Lamentations}

Before embarking on the Sugirtharajah-suggested postcolonial reading of the book of Lamentations, a general overview of the book is in order.

Authorship: Despite the age-old textual as well as interpretive traditions' ascription of the authorship to prophet Jeremiah, ${ }^{10}$ the majority contemporary critical scholarship does not subscribe to such a view on account of thematic shifts as well as contrasting theological outlooks between Jeremiah and Lamentations. Nonetheless, the graphic description of the "lonely city" (1.1.) and the devastation all around (Chaps. 1 and 2) indicate that the books is most likely the eyewitness accounts of the fall of Jerusalem, ${ }^{11}$ particularly by those who were on the ground and experiencing the monumental disaster. ${ }^{12}$

8 Walter Brueggemann, An Unsettling God:The Heart of the Hebrew Bible (Minneapolis, MN: Fortress Press, 2009). Walter Brueggemann, Hopeful Imagination: Prophetic Voices in Exile (Philadelphia, PA: Fortress Press, 1986).

9 Karen Baker-Fletcher, Dancing with God:The Trinity from a Womanist Perspective (St. Louis, MO: Chalice Press, 2006).

10 The Septuagint (the oldest Greek version of the Old Testament) explicitly ascribes to Jeramian authorship. The same is followed and even expanded by the rabbinic tradition. See Adele Berlin, Lamentations: A Commentary, OTL (Louisville, KY: Westminster John Knox, 2004), 30-32. Gina Hens-Piazza, Lamentations, ed. Carol J. Dempsey, Wisdom Commentary 30 (Collegeville, MN: Liturgical Press, 2017), xlviii-xlix.MN","number-of-pages":"154","source":"Google Books","event-place”:"Collegeville, MN","abstract":"Though the five poems of Lamentations undoubtedly refer to the Babylonian siege and destruction of Jerusalem in 587 BCE, the multiple voices that narrate unspeakable suffering and labor to make sense of the surrounding horror do so at women's expense. In the opening chapters, a prevailing metaphor of Jerusalem as a woman (Woman Zion

11 See, John Guest, Jeremiah, Lamentations, The Preacher's Commentary Series 19 (Nashville, TN: Thomas Nelson, 1988), 349. However, for a counter view, see Berlin, Lamentations, 33.

12 Hens-Piazza, Lamentations, xxxix.MN","number-of-pages":"154","source":"Google Books","event-place":"Collegeville, MN","abstract":"Though the five poems of Lamentations undoubtedly refer to the Babylonian siege and destruction of Jerusalem in $587 \mathrm{BCE}$, the multiple voices that narrate unspeakable suffering and labor to make sense of the surrounding horror do so at women's expense. In the opening chapters, a prevailing metaphor of Jerusalem as a woman (Woman Zion 
Content: The overwhelming anguish at the fall of the most cherished city is aptly captured in the very first word of the book: it is a great sigh - "Alas!" ("ekah in Hebrew; which, as per the convention of the Hebrew Bible, is also the title of the book). ${ }^{13}$ It is a standard opening word for a dirge (cf. Isa 1:21) but can also express reproach (cf. Jer 8:8). ${ }^{14}$ Though Lamentations is comparatively a small corpus, consisting of only five chapters, the book exhibits an extraordinary literary structure. Thematically, each chapter is self-contained. Further, the first four chapters are acrostic (Hebrew alphabetic) poems. That a devastation and destruction of such enormity is rendered in this orderly fashion is, to say the least, unique and intriguing. All the same and as though reflecting the de-settling destruction that the book depicts, the final poem deviates from the acrostic style. Further, book itself ends on an unresolved note. ${ }^{15}$ Despite the passionate outpouring that fills the book, God's voice is never heard in the entire corpus.

Purpose: Why should a grotesque picture of unrelenting grief be placed in an otherwise much revered Bible? The scholarly responses to this question come in various shades. In fact, they can be plotted on a continuum that spans between two extremes. On the one extreme lays the position of apologetic/spiritualizing explanation ${ }^{16}$ while on the other end is constituted by radical response that calls for excising the book from the Bible. Thankfully, a meaningful middle is advocated by majority of scholars. ${ }^{17}$ For instance, "the lack of historical specificity in Lamentations," Gina Hens-Piazza opines, "allows for a timelessness regarding the

13 On the word's double significance, see Guest, Jeremiah, Lamentations, 350.

14 Cf. HALOT 410.

15 Cf. Conclusion, below. For an appealing, animated, and quick overview of the book of Lamentations, see Tim Mackie and Jon Collins, "Lamentations: Bible Project," June 30, 2016, https: / / www.youtube.com/watch?v=p8GDFPdaQZQ.

16 Matthew Henry et al., The Bethany Parallel Commentary on the Old Testament (Minneapolis, MN: Bethany House, 1985), 1651.

17 While scholars such as Naomi Seidman and Deryn Guest call for excising the book from the canon, Hens-Piazza offers a number of valid reasons for claiming the book. See Hens-Piazza, Lamentations, xlii-xliii.MN","number-of-pages":"154","source":"Google Books","event-place":"Collegeville, MN","abstract":”Though the five poems of Lamentations undoubtedly refer to the Babylonian siege and destruction of Jerusalem in $587 \mathrm{BCE}$, the multiple voices that narrate unspeakable suffering and labor to make sense of the surrounding horror do so at women's expense. In the opening chapters, a prevailing metaphor of Jerusalem as a woman (Woman Zion 
suffering." 18 As already stated, for the present paper, the dialogic reading of Mandalfo constitutes a significant part of conversation. Her dialogic reading juxtaposes the marriage metaphor (that pits a faithful Yahewh against Yahweh's wanton wife, Israel/Zion) in the prophetic literature and the protesting voice of Daughter Zion in Lamentations $1-2$ and how the latter lays bare the bankrupt theology in the prophetic portrayals. For the present purpose of delineating the postcolonial construal that inform the dialogic reading of Mandalfo, the next section begins with an overview of postcolonial criticism-first, in general and then in the biblical area.

\section{Postcolonial Criticism and Postcolonial Biblical Criticism}

Postcolonial Criticism: In charting the contours of Postcolonial criticism, its widely published proponent in the biblical arena, R. S. Sugirtharajah, ${ }^{19}$ observes that "in its earlier incarnation, postcolonialism was never conceived as a grand theory, but as creative literature and as a resistance discourse." ${ }^{20}$ That it had its original impetus not in any grandiose theory but the praxis needs mentioning. Building on the momentum that was provided by activists and critics, enduring theoretical contributions to the same were rendered by creative and critical writers such as Frantz Fanon, Aimé Césaire, Albert Memmi and C.L.R. James. The global attention, however, turned definitely towards postcolonialism when a widely-received as well as vigorously critiqued work of Edward Said, Orientalism, ${ }^{21}$ appeared. Of the many thought-provoking insights,

18 Yet, Hens-Piazza avers, it is done “at women's expense.” See Hens-Piazza, xl.MN”,"number-of-pages":"154","source”:"Google Books","event-place”:"Collegeville, MN”,"abstract":"Though the five poems of Lamentations undoubtedly refer to the Babylonian siege and destruction of Jerusalem in $587 \mathrm{BCE}$, the multiple voices that narrate unspeakable suffering and labor to make sense of the surrounding horror do so at women's expense. In the opening chapters, a prevailing metaphor of Jerusalem as a woman (Woman Zion

19 This subsection draws from a detailed discussion in R. S. Sugirtharajah, Exploring Postcolonial Biblical Criticism: History, Method, Practice (West Sussex: Wiley-Blackwell, 2012), 7-30 (11-12).

${ }^{20}$ R. S. Sugirtharajah, "Charting the Aftermath: A Review of Postcolonial Criticism," in The Postcolonial Biblical Reader, ed. R. S. Sugirtharajah (Malden, MA: Blackwell, 2008), 7.

21 Edward W. Said, Orientalism, 25th Anniversary ed. (New York: Random House, 1994). On the lingering impact of Said's work, see Leela Gandhi, Postcolonial Theory: A Critical Introduction (Crows Nest, NSW: Allen \& Unwin, 1998). 
the Western "representation" of the "Orient" (and hence the book's title) came under Said's penetrating critical gaze. Two other prominent thinkers who are credited to have furthered the postcolonial theoretical findings are Gayatri Spivak and Homi Bhabha. While the former problematizes the question of representability by people at the peripherynamely, the subalterns, ${ }^{22}$ the latter focused on the liminality that attends the (post)colonial discourses. ${ }^{23}$

Postcolonial Biblical Criticism: While 1980s witnessed the arrival of postcolonial criticism in the humanities departments, its promising reading strategies were introduced to the field of biblical interpretation in 1990s. As one of the key areas of inquiry of postcolonial criticism was to challenge "the way the texts and knowledge were produced and interpreted, the Christian Bible and the biblical interpretation ... [became its]

22 See Gayatri Ch. Spivak, Can the Subaltern Speak? Reflections on the History of an Idea, ed. Rosalind C. Morris (New York: Columbia University Press, 2010)."number-of-pages":"340","source":"Google Books","event-place":"New York","abstract":"Gayatri Chakravorty Spivak's original essay \"Can the Subaltern Speak? \" transformed the analysis of colonialism through an eloquent and uncompromising argument that affirmed the contemporary relevance of Marxism while using deconstructionist methods to explore the international division of labor and capitalism's \"worlding $\backslash$ " of the world. Spivak's essay hones in on the historical and ideological factors that obstruct the possibility of being heard for those who inhabit the periphery. It is a probing interrogation of what it means to have political subjectivity, to be able to access the state, and to suffer the burden of difference in a capitalist system that promises equality yet withholds it at every turn. Since its publication, \"Can the Subaltern Speak? \” has been cited, invoked, imitated, and critiqued. In these phenomenal essays, eight scholars take stock of the effects and response to Spivak's work. They begin by contextualizing the piece within the development of subaltern and postcolonial studies and the quest for human rights. Then, through the lens of Spivak's essay, they rethink historical problems of subalternity, voicing, and death. A final section situates \"Can the Subaltern Speak?\” within contemporary issues, particularly new international divisions of labor and the politics of silence among indigenous women of Guatemala and Mexico. In an afterword, Spivak herself considers her essay's past interpretations and future incarnations and the questions and histories that remain secreted in the original and revised versions of \"Can the Subaltern Speak? \"?both of which are reprinted in this book.", ISBN":"978-0-231-14385-1","note":"Google-Books-ID: aNJoCQtDUM4C","shortTitle":"Can the Subaltern Speak?","language”:"en”,"editor”:[\{“family":”Morris","given”:”Rosalind C.”\} ],"author":[ \{“family”:”Spivak”,"given”:"Gayatri Ch.”\}],"issued": ““date-parts":[[“2010”]]\}\}\}],"schema”:"https: / / github.com/citation-style-language/schema/raw/master/csl-citation.json”\}

23 See Homi K. Bhabha, The Location of Culture (London: Routledge, 1994). 
natural candidates." ${ }^{24}$ In reading a biblical text, postcolonial criticism typically poses questions such as: ${ }^{25}$

1. Where does the author's loyalties lie: with the hegemonic power or the subjugated?

2. How are the victims represented?

3. Does the text grant space for the resistance from the same victims?

4 . How can the victims' story be recuperated?

Such recuperation, according to Sugirtharajah, involves "retrieval" as well as "dissident hermeneutics" 26 — the hermeneutics that pays particular attention to how even amidst the maligned depiction of the victims, the latter is found responding in ways that are at once creative (thus claiming agency for oneself) and unsettling (the hegemonic discourse).

For the present purpose, the focus will be limited to some "construal of postcolonial criticism" that Sugirtharajah outlines ${ }^{27}$ as well as illustrating the same by drawing from some of the commentators' assiduous attention to Daughter Zion's talk back, as attested in the book of the Lamentations. Later, by highlighting comparable construal in Dalit strategies - both discursive and otherwise - one of the key tasks of this paper will be presented: in Dalits, we can meaningfully find a contemporary sibling to Daughter, both in pain and protest.

\section{A Postcolonial Reading of the Book of Lamentations}

The "Others" taking their place: "Postcoloniality involves the once-colonized 'Others' insisting on taking their place as ... subjects." 28 By this, the subjugated and sidelined "Other" makes a confident entry into the discursive space and claims one's rightful place as a dialogue partner. Such a bold move has the promising possibility of releasing the "Other" from one's marginal status.

24 Sugirtharajah, Exploring Postcolonial Biblical Criticism, 42.

${ }^{25}$ For a complete list, together with pertinent biblical examples, see Sugirtharajah, 4654.

26 For details, see Sugirtharajah, 48-49.

27 For the construal, see R. S. Sugirtharajah, Asian Biblical Hermeneutics and Postcolonialism: Contesting the Interpretations (Sheffield: Sheffield Academic, 1999), 15-18.

28 Sugirtharajah, 16. 
Within the book of Lamentations, chapter 1 begins with a description of the destruction of Jerusalem. And Daughter Zion is silent for the first 9 verses. However, all on a sudden, she "interrupts the narrator's speech in response to his [narrator's] description of her fallen, dishonored state and the absence of a comforter (vv. 7-9)." ${ }^{29}$ In the midst of her unbearable suffering, she appeals for notice and comfort. Of particular significance is her turn to Yahweh and the passionate plea to the latter to pay attention to her misery (v.9c). More power will be packed to her appeal which will metamorph into outbursts against Yahweh in Lamentations 2. For now, it is pertinent to note that, though betrayed and beaten, desolate and downcast, the very voice of Daughter Zion and her appeal attest to her new found courage to speak out her concerns, take her due place in the narrative and thus claim her subjectivity.

Hybridized Identity: Postcoloniality also highlights how the victimized "Other" dares to construct a new identity. However, the identity is achieved neither by a denial of the colonially given one nor by inventing a totally novel identity. Rather, it is a creative negotiation between the two where an imaginative redeploying of local and the imported elements are forged together. ${ }^{30}$

In the biblical tradition, divine wrath is often directed against God's as well as Israel's enemies (cf. Isa 13; Ezek 7; Amos 5:18-20). But Lamentations turns the tables on Israel. ${ }^{31}$ God's own people became the target of divine wrath, resulting in the desolation of the city. ${ }^{32}$ According to the marriage metaphor as imagined by of the prophets, the reason for such a wrath is the promiscuous behavior of Zion (Hos 1-3; Jer 2-3; Ezek 16, 23). Thus the dominant prophetic narrative places the blame

${ }^{29}$ Elizabeth Boase, The Fulfilment of Doom? The Dialogic Interaction between the Book of Lamentations and the Pre-Exilic/Early Exilic Prophetic Literature, LHBOTS 437 (London:T \& T Clark International, 2006), 212.

30 On hybridized identity, see Sugirtharajah, Asian Biblical Hermeneutics and Postcolonialism, $16-17$.

31 The book of Amos employs a comparable reversal when it speaks of the Day of the LORD (Amos 5:18-20; cf. Zeph 1:4, 7, 14).

32 See Guest, Jeremiah, Lamentations, 351. Hens-Piazza, Lamentations, 95.MN","number-of-pages":"154","source":"Google Books","event-place":"Collegeville, MN","abstract":"Though the five poems of Lamentations undoubtedly refer to the Babylonian siege and destruction of Jerusalem in $587 \mathrm{BCE}$, the multiple voices that narrate unspeakable suffering and labor to make sense of the surrounding horror do so at women's expense. In the opening chapters, a prevailing metaphor of Jerusalem as a woman (Woman Zion 
squarely on Zion, the supposedly wanton wife of Yahweh. However, in Zion's response, "the identity she crafts for herself is that of the victimized woman and bereft mother in contrast to the villain of Jeremiah's 'narrative." ${ }^{33}$ In short, she is above all a bereaving mother. She thus shifts the spotlight away from the marriage metaphor and the associated image of herself as the "wanton" wife to a wailing mother who bemoans the loss of her children.

Discursive Resistance: Corollary to the hybridized identity is the manner in which such an identity is constructed. So, postcolonial criticism engages in "active interrogation of the hegemonic systems of thought, textual codes, and symbolic practices ... It is a discursive resistance ... as an alternative way of perceiving and restructuring society." ${ }^{34}$

In using shocking and shaming metaphors, ${ }^{35}$ the dominant prophetic discourse was interested in the power dynamics of God's unconditional control of his people. Daughter Zion's counter-story resists exactly that, and to a certain extent, subverts the dominant prophetic discourse. "The theological assumption behind the prophetic warnings ... is that Jerusalem is justifiably punished for her sins, that she is reaping what she sowed." ${ }^{36}$ In contrast, the message of the book of Lamentations "is not Zion's acknowledgement of her sin, is not an attempt at repentance ... but rather is meant mostly as an emotional expression of existential pain, shock, and betrayal." ${ }^{37}$ It is further underscored when, for example, the narrator in Lam 2 instructs her to appeal to "God as her only hope (2:18-19), she only pours out her rage, but never seeks for mercy $(2: 20-22) . " 38$

From the Margins to the Forefront: When the "Others" take their rightful place and construct a hybrid identity by means of discursive resistance, the end result cannot but be the arrival of those at the margins to the forefront. As such, postcolonial criticism brings "marginal ele-

33 Mandolfo, Daughter Zion Talks Back To The Prophets, 89.

34 Sugirtharajah, Asian Biblical Hermeneutics and Postcolonialism, 17.

35 To learn that one's wife is sexually involved with other men would have had a damaging and devastating impact on the husband in Ancient Near East. For further discussion, see Mandolfo, Daughter Zion Talks Back To The Prophets, 26.

36 Mandolfo, 84.

37 Mandolfo, 84.

38 Mandolfo, 69. 
ments to the front, and in the process, subverts the traditional meaning. It engages in archival exegesis as a way of rememorializing the narratives and voices which have been subjected to institutional and exegetical forgetting." 39

Employing dialogic hermeneutics, Mandolfo draws our attention to the need "to read with Daughter Zion and toward God/male as object, thus automatically restoring the woman to a subject position." ${ }^{40}$ One of the ways to achieve this is to read the prophetic texts in a gap-filling way, namely, to pay attention to the things that the dominant discourse omits or wants us, the readers, to omit. "Postcolonial criticism recognizes that the interpreters have to be freed from traditional interpretative powers so that the voice of the voiceless may be heard." 41 For instance, the doctrine of retribution, ${ }^{42}$ which the text of Jeremiah uses as its basis, is rightly challenged by Daughter Zion's portrayal of her disproportionate suffering - that too in the hand of the one who should have been her protector. $^{43}$

The discussion thus far delineated some of the salient traits of postcolonial perspectives together with illustrations of their usefulness in reading biblical texts by culling out some of the commentators' insightful observations on Lamentations $1-2$. With these as the backdrop, the next section shifts the spotlight on one other but more contemporary instance of resistance discourse, akin to Zion's. It is from the one from the marginalized Dalit communities of Indian subcontinent.

\section{Daughter Zion's Contemporary Sibling: The Dalits}

Daughter Zion characteristically represents the "colonized object" by

39 Sugirtharajah, Asian Biblical Hermeneutics and Postcolonialism, 22.

40 Mandolfo, Daughter Zion Talks Back To The Prophets, 83.

41 Sugirtharajah, Asian Biblical Hermeneutics and Postcolonialism, 18.

42 See Alan L. Mintz, Hurban: Responses to Catastrophe in Hebrew Literature (New York: Columbia University Press, 1984), 23. As cited in Bier, "Perhaps There Is Hope," 10.

43 For further details, see Mandolfo, Daughter Zion Talks Back To The Prophets, 90. See also, Hens-Piazza, Lamentations, xliii.MN","number-of-pages":"154","source":"Google Books","event-place":"Collegeville, MN","abstract":"Though the five poems of Lamentations undoubtedly refer to the Babylonian siege and destruction of Jerusalem in 587 $\mathrm{BCE}$, the multiple voices that narrate unspeakable suffering and labor to make sense of the surrounding horror do so at women's expense. In the opening chapters, a prevailing metaphor of Jerusalem as a woman (Woman Zion 
the "colonizing subject," which is the prophetic narratives that employ the marriage metaphor. As already indicated, she is not without company - even in our world today. The ritually despicable and socially ostracized community, called "Dalits," in India share Zion's predicaments in more than one way. In a remarkable similarity, the literature that stems from this often dehumanized community bears significant postcolonial features. This should hardly surprise us. After all, as Sugirtharajah has rightly averred, Postcoloniality will "emerge among nations, communities, and groups which have been victims of the old imperialism and are now victims of the current globalization, and who have been kept away from power." ${ }^{44}$ Hence, the counter-stories of Dalits can be meaningfully juxtaposed with the outcry of Daughter Zion.

\section{Dalits-The Untouch-} ables: "More than 160 million people in India are considered 'Untouchable'-people tainted by their birth into a caste system that deems them impure, less than human." 45 Although comprising of "wider conglomeration of ethnic groups," they represent about 20 percent of India's population and yet most of them still suffer from their segregated state. ${ }^{46}$ Curiously, as Hans

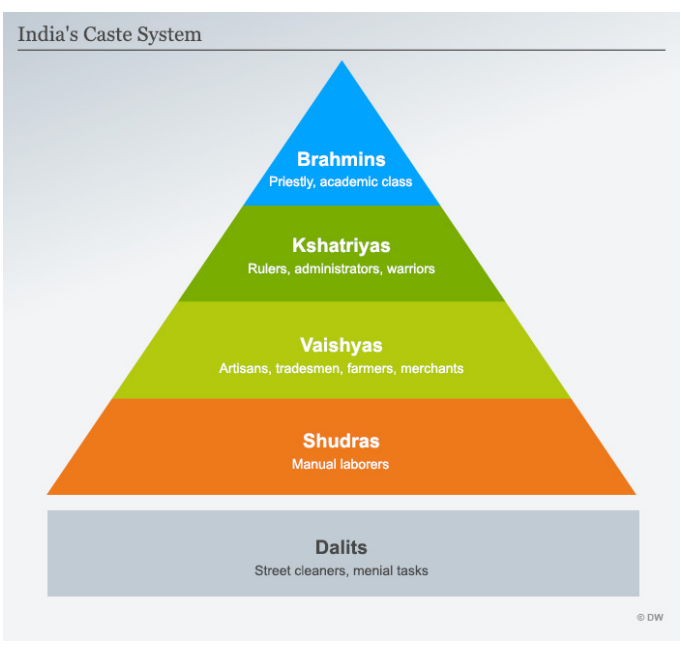
Ucko observes, Dalits were "the rulers of India before the advent of the Aryans. They have never been Hindus. They are a different race. They have survived 4000 years of oppression ... They are the base of the pyramid [cf. the picture]... They are the oppressed and poor, economically

${ }^{44}$ Sugirtharajah, Asian Biblical Hermeneutics and Postcolonialism, 17.

${ }^{45}$ Hillary Mayell, "India's “Untouchables” Face Violence, Discrimination," National Geographic News, June 2, 2003. Yet, on the bargaining value of such a staggering number (160 million) together with the paradoxically continued state of deprivation, see Clarinda Still, ed., Dalits in Neoliberal India: Mobility or Marginalisation?, Exploring the Political in South Asia (London: Routledge, 2014).

${ }^{46}$ See Hans Ucko, The People and the People of God: Minjung and Dalit Theology in Interaction with Jewish-Christian Dialogue, Ecumenical Studies 17 (Münster: LIT Verlag, 2002), 117-18. Drawing on James Massey's findings on the linguistic relationship between "Dalit" and "dal" (in Hebrew), Ucko offers an intriguing discussion on the term "Dalit". 
and socially." 47

Maligned and marginalized, segregated and sidelined, the Dalits of the last few decades have pooled together their, often scanty, resources to resist, counter and cry out against various forms of oppression. Of particular significance for the present purpose is the discursive resistance that has come to characterize the Dalit literature. It would therefore bear to highlight some of such resistance strategies and group them around the postcolonial features that Sugirtharajah presents, ${ }^{48}$ which were employed here to highlight Daughter Zion's dialogical strategies.

The "Others" Taking their Place: Among the Dalits, of late, there has been a growing sense of the need to assert themselves socially, economically and politically. The political assertion is the most prominent and the easily noticed. As Pushpedra observes, "The post-independence period has seen democratic institutions gaining greater legitimacy among the scheduled castes, who having grown conscious of their numerical strength in electoral arena, are exercising their voting right more forthrightly." ${ }^{49}$ Bahujan Samaj Party, which arose from the dusty quarters of the Dalits in Utter Pradesh (one of the northern states in India) presents a pertinent case. In the early 2000s, the state witnessed to a Dalit woman (Ms. Mayawati) being elected to the highest post in the state: The Chief Minister (2007-12). All such growing assertions have reciprocal bearings on the nascent Dalit literature in the country.

As regards Dalit literature, D. R. Nagaraj observes that "[t]here are two different modes of Dalit writing, and they can be called the Schools of Social Rage and Spiritual Quest. The social rage mode concentrates

47 Ucko, 118. Picture source: Timothy Jones, “India’s Caste System: Weakened, but Still Influential | DW | 17.07.2017," dw.com, July 17, 2017, https://www.dw.com/en/ indias-caste-system-weakened-but-still-influential/a-39718124.the caste system in India continues to have a strong impact on society. DW explains how it evolved and what the situation in the country is now.", "URL":"https://www.dw.com/en/indias-caste-system-weakened-but-still-influential/a-39718124","shortTitle":"'India's caste system”,"language”:"en_GB”,"author": [ “family":”Jones”,"given”:”Timothy” \}],"issued": \{“date-parts":[[“2017”,7,17]]\},"accessed": \{“date-parts":[[“2018”,8,17]]\}\}\}],"s chema”:"https: / / github.com/citation-style-language/schema/raw/master/csl-citation.json"\}

Cf. subsection 4, above.

49 Pushpendra, "Dalit Assertion through Electoral Politics," Economic and Political Weekly 34, no. 36 (1999): 2609. 
basically on the experiences of anger, agony and revolutionary hope." 50 The very voicing of one's outburst and anger is a powerful attestation to the marginal "Other" taking their rightful place, particularly in the discursive arena, much like the manner in which Daughter Zion claims her due space in Lamentations 1-2.

Hybridized Identity: Mahatma Gandhi is a globally-known Indian freedom figure who championed non-violent protests against the colonial British. His chosen parlance for the Dalits provides a pertinent case study for the identity that the Dalits have dared to construct for themselves. Gandhi used the word "Harijans"51 ("god's people") in his reference to the untouchables. However, since that definition came from a dominant Brahminical background and also the alluded meaning effectively glosses over the age-old oppression that the Dalits have suffered, the term "Harijans" has been scorned by the oppressed group. In its stead, the leaders of these subjugated communities have preferred to use the word "Dalit." Ucko helpfully highlights how "Dalit" is more than a mere choice of a term: "Adopting the term Dalits for themselves, they seek to abolish not only untouchability, but the caste system that has given birth to it and continues to nurture it." ${ }^{2}$ For instance, the use of the word "Dalit" - which literally means "broken" or figuratively "the exploited" - the community identifies its oppressors, the non-Dalits who are the cause of their dehumanization. ${ }^{53}$ Thus, the word at once makes present both the victimized state of the Dalits as well as their passionate effort at asserting their subjective agency.

Discursive Resistance: Of the many characteristic features of Dalit literature, their discursive resistance and reversal of hegemonic constructs is a well attested one. A couple of illustrations should suffice to highlight the same. While beef-eating as well as drum-playing are often denigratingly associated with Dalit communities in order to underscore their ostracized social status, Dalit literature has turned the same into means of asserting their rightful status by valorizing beef-eating and by

${ }^{50}$ D. R Nagaraj, The Flaming Feet: A Study of the Dalit Movement in India (Michigan: South Forum Press, 1993), 62. While the School of Spiritual Quest is positively viewed by the members of other caste groups, the Social Rage group is either suspected of its mixed motivation or, when possible, silenced. See, Nagaraj, 63.

51 "Harijan" is a combination of two Sanskrit words: 'Hari' means 'god' and 'Jan' means 'people'. In a broad sense "Harijan", therefore, can be translated as "god's people”.

52 Ucko, The People and the People of God, 118.

${ }^{53}$ For further details, see Ucko, 118. 
infusing new meaning into denigrated symbols. A clear example in this regard is the novel yet liberative theological imagination which flips an otherwise despised symbol of drum into a quintessential one when Dalits depict "Jesus as the drum!" 54 An accompanying feature of such resistance discourse is the tone of denigration or ridicule that characterizes the Dalit depiction of their oppressors. Nagaraj, for instance, observes that in Dalit literature, the oppressing group "is recreated in the vast interiority of the Dalit world ... Big landlords are reduced to ridiculous miniatures in the eyes of the landless and luckless ones... To use a Zen metaphor, the distant hills are recreated in the eyes of a bird." 55

From the Margins to the Forefront: There are many forms of marginalization that the Dalits suffer. Some of which - prohibition from accessing village resources such as the drinking water well or entrance to the temple - are quite obvious. While others are much more subtle. Of the latter category is the denigrating dichotomy that is painted between orality and literacy. Whereas Dalit heritage is rich in oral traditions, the same comes under the dismissing gazes of the hegemonic ones who take pride in their written resources. In other words, as Purushottama Bilimoria and Andrew B. Irvine observe, "The marginalized humanity has no scriptures like Vedas and Upanisads, so they are empty and naked and have nowhere to go." ${ }^{56}$ Despite the fact that the Dalit community has no scriptures, their marginal voice come to the forefront in the form of folksongs. One such expression is the Bow Songs. Each Bow Song is a commemoration of a Dalit man or a Dalit woman who suffered and was finally done away by the hegemonic powers. If in killing such persons, the oppressive regimes wished to obliterate the memory of an individual and thus induce fear in Dalit community, the repeated performance of Bow Songs achieves the opposite purposes: perpetuated memory and power-asserting proclamation.

Each Bow Song performance is "commonly demarcated into two ritually distinct segments. In the first, "the birth, youth, and (optionally) the marriage of the main figure' builds up to a violation ... The outcome is

54 For further details, together with relevant resources, see my comments in Dominic S. Irudayaraj, "Idol-Taunt and Exilic Identity," in Myths of Exile: History and Metaphor in the Hebrew Bible, ed. Anne K. H. Gudme and Ingrid Hjelm, 1st ed., Copenhagen International Seminar (London: Routledge, 2015), 127-29.

55 Nagaraj, The Flaming Feet, 62.

56 Purushottama Bilimoria and Andrew B. Irvine, eds., Postcolonial Philosophy of Religion (Switzerland: Springer, 2009), 100. 
then the hero or heroine's 'cruel, undeserved death' ... In segment two, the victim is deified who, it is believed, would then come to avenge their violators $!^{57}$ In celebrating the prematurely snuffed out lives of men and women of their community, Dalits not only perpetuate the memories of those departed but also locate their newfound courage in the gods and goddesses that the same dead ones have now been turned into.

\section{Theological Ramifications}

The discussion thus far has endeavored to highlight comparable features in the ways Daughter Zion and Dalit community attempt to make meaning of their existential—often traumatic—experiences. To do so, some salient features of postcolonial criticism served as the guideposts. To summarize, a community that goes through shattering experience ends up producing literature as one of the ways of coping with the crisis. Such works bear certain characteristic marks. When we encountering such texts, what theological ramification we, as readers, can draw from those passionate, identity-affirming discourses? Three biblical interpreters provide helpful approaches in engaging such crisis-generated and trauma-driven discourses. Their views, though at first glance may appear diverse, complement and constitute a meaningful path towards a pertinent response.

First, Brueggemann who builds on his notion of 'God-in-relationship'58 suggests that when faced with traumatizing suffering, 'dialogue' ought to become as an important disposition of one's faith. In the case of Israel, as Brueggemann observes, "Israel in exile is a community that grieves and protests ... The practice of grief is an exercise in truth-telling $\ldots$ an exercise in massive sadness that acknowledges, with no denial or deception, where and how Israel is." ${ }^{59}$ It is the same grief that spills over into protesting tone, even against YHWH. As such, "Israel is not willing to let YHWH off the hook." ${ }^{60}$ And the end result is equally worth noting. The shrill counter-voice and the daring defiance of Israel eventually talks "YHWH into something YHWH had not yet entertained or imagined

57 For details, see Alf Hiltebeitel, Rethinking India's Oral and Classical Epics: Draupadi among Rajputs, Muslims, and Dalits, 1st ed. (Chicago: University Of Chicago Press, 1999), 29.

58 For a detailed discussion on Hebrew Bible's notion of God as God-in-relationship, see Brueggemann, An Unsettling God.

59 Brueggemann, 41.

60 Brueggemann, 41. 
or intended." 61 True grief can, even in the midst of groaning and questioning God, talk God into something God could not have intended. ${ }^{62}$ This dynamism of conter-voice within the context of God-in-relationship thus forms a sturdy foundation for a healthy meaning-making process in the face of immense suffering.

Secondly and as it has already been pointed to, Mandolfo ${ }^{63}$ has rightly drawn our attention to the fact that the "prophetic texts that use marriage metaphor' does a gross violation in their depiction of Daughter Zion. Such a rendering does not only reduce an otherwise dialogue to monologue but also amount to irresponsible authoring. It is, therefore, appropriate that Daughter Zion protests, complains, and even subverts the way God reaches - or does not reach - out to her. The active engagement of the divine in moment of crisis must stem from faith in a 'God-in-relationship.' Hence, for instance, in her protest against God, Daughter Zion does not flee from the scene in passive resignation; rather she engages God.

Finally, Baker-Fletcher aesthetically imagines such active engagement as 'dancing with God.' 64 "The context of theological praxis is not evil, death, and violence but the goodness of God ... To focus on evil, as if that were the primary existential context, spirals heart, mind and God-given gifts for ministry down into the pit of hopelessness." ${ }^{65}$ Baker-Fletcher's focus is, therefore, more praxis-oriented. "The context of theology in a world of crucifixion is life." ${ }^{66}$ To sum up, if Bruggemann's God-in-relation forms the foundation, Mandolfo's counter-discourse offers the dynamism involved in such a relationship, the same is consummated in the praxis-oriented and life-centered dancing-with-God that Baker-Fletcher proposes.

61 Brueggemann, 44.

62 For a persuasive discussion on how true grief paves way for new possibility, see Brueggemann, Hopeful Imagination: Prophetic Voices in Exile.

63 Using dialogic hermeneutics, Mandolfo draws our attention to the voice of Daughter Zion in the book of Lamentations. For further details, see Mandolfo, Daughter Zion Talks Back To The Prophets.

${ }^{64}$ For a detailed discussion on engaging God in a world of unnecessary suffering, see Baker-Fletcher, Dancing with God:The Trinity from a Womanist Perspective.

65 Baker-Fletcher, 38.

66 Baker-Fletcher, 39. 
In his reflection on the tasks of a theologian, David Blumenthal points out that to be a theologian is "to speak for God." But that is not the end. "To be a theologian is [also] to put back together the pieces of broken awareness and shattered relationship. Great is the suffering of our fellow human beings, and deep is the estrangement between them and God. The theologian must be a healer of that relationship." ${ }^{67}$ Such a two-fold task necessitates that's he has to "be in solidarity with one's fellow human beings before God. It is to take the heart of other to God. To bless and to share blessing, to be angry and to share rage ... to talk to God for the people, to address God on their behalf. It is to be angry with God, for them. It is to praise God, with them." 68 Blumenthal, thus, highlights an important aspect in a theologian's task: the preferential option to be the voice of the neglected ones. Postcolonial criticism adds exactly that nuance to the responsibility of a theologian. "Reading the Bible from a postcolonial perspective implies removing the colonial assumptions and ideologies on which much of the text rests." ${ }^{69}$ One important way of achieving such a salient end is to look for and listen to the "oppositional and protest voices." 70 It is a conscious choice to be with and to speak for the voiceless, nameless and hopeless.

\section{Conclusion}

People who have survived atrocities often tell their stories in a highly emotional, contradictory, and fragmented manner ${ }^{71}$

In a way, this paper is an effort at listening to two such emotional, contradictory and fragmented stories: the one of Daughter Zion and that of Dalit community. A postcolonial reading rightly brings out the characteristic marks shared by these two stories: the neglected "Others" taking their due places, their attempt at defining a hybridized identity for themselves by working through and, in the process, subverting the dominant story and, thus, explicating their discursive resistance which brings the marginal elements to the forefront.

${ }^{67}$ David R. Blumenthal, Facing the Abusing God:A Theology of Protest, 1st ed. (Louisville, KY: Westminster John Knox, 1993), 3.

${ }^{68}$ Blumenthal, 4.

${ }^{69}$ Sugirtharajah, Asian Biblical Hermeneutics and Postcolonialism, 20.

${ }^{70}$ Drawing from the insights of Stuart Hall, Sugirtharajah highlights the nuanced task of a postcolonial reader. For details, see Sugirtharajah, 21.

71 Judith Herman, Trauma and Recovery:The Aftermath ofViolence--from Domestic Abuse to Political Terror (New York: Basic Books, 1997), 1. 
The task of any committed reader therefore is to pay attention, listen carefully, and make the courageous commitment to be the voice of voiceless. And there is a curious clue in the book of Lamentations. It is the way the book ends. The voice of God is absent throughout the book and an ardent cry of appeal is made to God at the end. "Restore us to yourself, O Lord ... unless you have utterly rejected us" (5. 21-22). True, the book "closes with doubt, but leaves open the possibility that there will be a future word from Yahweh." 72 In the meantime, it is our task to stand in solidarity with the crisis-ridden communities in their engagement with God, in their protest and anger, and in their continual dance with God!

\section{BibliograPhy}

Baker-Fletcher, Karen. Dancing with God: The Trinity from a Womanist Perspective. St. Louis, MO: Chalice Press, 2006.

Berlin, Adele. Lamentations: A Commentary. OTL. Louisville, KY: Westminster John Knox, 2004.

Bhabha, Homi K. The Location of Culture. London: Routledge, 1994.

Bier, Miriam J. "Perhaps There Is Hope": Reading Lamentations as a Polyphony of Pain, Penitence, and Protest. LHBOTS 603. London: Bloomsbury T\&T Clark, 2015.

Bilimoria, Purushottama, and Andrew B. Irvine, eds. Postcolonial Philosophy of Religion. Switzerland: Springer, 2009.

Blumenthal, David R. Facing the Abusing God: A Theology of Protest. 1st ed. Louisville, KY: Westminster John Knox, 1993.

Boase, Elizabeth. The Fulfilment of Doom? The Dialogic Interaction between the Book of Lamentations and the Pre-Exilic/Early Exilic Prophetic Literature. LHBOTS 437. London: T \& T Clark International, 2006.

Boase, Elizabeth, and Christopher G. Frechette. Bible through the Lens of Trauma. SBL Semeia Studies 86. Atlanta, GA: SBL Press, 2016.

Brueggemann, Walter. An Unsettling God: The Heart of the Hebrew Bible. Minneapolis, MN: Fortress Press, 2009.

- Hopeful Imagination: Prophetic Voices in Exile. Philadelphia, PA: Fortress Press, 1986.

Gandhi, Leela. Postcolonial Theory: A Critical Introduction. Crows Nest, NSW: Allen \& Unwin, 1998.

72 Boase, The Fulfilment of Doom?, 208. 
Guest, John. Jeremiah, Lamentations. The Preacher's Commentary Series 19. Nashville, TN: Thomas Nelson, 1988.

Henry, Matthew, Robert Jamieson, Andrew Fausset, and David Brown. The Bethany Parallel Commentary on the Old Testament. Minneapolis, MN: Bethany House, 1985.

Hens-Piazza, Gina. Lamentations. Edited by Carol J. Dempsey. Wisdom Commentary 30. Collegeville, MN: Liturgical Press, 2017.

Herman, Judith. Trauma and Recovery: The Aftermath of Violence--from Domestic Abuse to Political Terror. New York: Basic Books, 1997.

Hiltebeitel, Alf. Rethinking India's Oral and Classical Epics: Draupadi among Rajputs, Muslims, and Dalits. 1st ed. Chicago: University Of Chicago Press, 1999.

Irudayaraj, Dominic S. "Idol-Taunt and Exilic Identity." In Myths of Exile: History and Metaphor in the Hebrew Bible, edited by Anne K. H. Gudme and Ingrid Hjelm, 1st ed., 125-36. Copenhagen International Seminar. London: Routledge, 2015.

Jones, Timothy. "India's Caste System: Weakened, but Still Influential | DW | 17.07.2017." dw.com, July 17, 2017. https://www.dw.com/en/indias-caste-system-weakened-but-still-influential/a-39718124.

Kaes, Anton. Shell Shock Cinema: Weimar Culture and the Wounds of War. New Jersey: Princeton University Press, 2009.

Mackie, Tim, and Jon Collins. "Lamentations: Bible Project," June 30, 2016. https://www.youtube.com/watch?v=p8GDFPdaQZQ.

Mandolfo, Carleen R. Daughter Zion Talks Back To The Prophets: A Dialogic Theology of the Book of Lamentations. SBL Semeia Studies 58. Atlanta, GA: SBL, 2007.

Mintz, Alan L. Hurban: Responses to Catastrophe in Hebrew Literature. New York: Columbia University Press, 1984.

Nagaraj, D. R. The Flaming Feet: A Study of the Dalit Movement in India. Michigan: South Forum Press, 1993.

Pushpendra. "Dalit Assertion through Electoral Politics." Economic and Political Weekly 34, no. 36 (1999): 2609-18.

Said, Edward W. Orientalism. 25th Anniversary ed. New York: Random House, 1994.

Sobrino, Jon. Christology at the Crossroads: A Latin American Approach. Translated by John Drury. New York: Orbis Books, 1978. 
Spivak, Gayatri Ch. Can the Subaltern Speak? Reflections on the History of an Idea. Edited by Rosalind C. Morris. New York: Columbia University Press, 2010.

Still, Clarinda, ed. Dalits in Neoliberal India: Mobility or Marginalisation? Exploring the Political in South Asia. London: Routledge, 2014.

Stuhlmueller, Carroll, and Dianne Bergant. The Collegeville Pastoral Dictionary of Biblical Theology. Collegeville, MN: Liturgical Press, 1996.

Sugirtharajah, R. S. Asian Biblical Hermeneutics and Postcolonialism: Contesting the Interpretations. Sheffield: Sheffield Academic, 1999.

—. "Charting the Aftermath: A Review of Postcolonial Criticism." In The Postcolonial Biblical Reader, edited by R. S. Sugirtharajah, 7-32. Malden, MA: Blackwell, 2008.

- Exploring Postcolonial Biblical Criticism: History, Method, Practice. West Sussex: Wiley-Blackwell, 2012.

Tambasco, Anthony J., ed. The Bible on Suffering: Social and Political Implications. New York: Paulist Press, 2001.

Ucko, Hans. The People and the People of God: Minjung and Dalit Theology in Interaction with Jewish-Christian Dialogue. Ecumenical Studies 17. Münster: LIT Verlag, 2002. 
